\title{
Managers Role in Redefining Performance Management
}

\author{
M.M. Shanmugapriya, B. Venkata Srilatha, Sumathi Arjunan
}

\begin{abstract}
The key factors that influence the performance of each company today, such as globalization, innovation, technology development, demography, society, respectively cause some changes in firms. These changes may have positive or negative effect on employees, therefore whole organization. Successful companies with long-term focus on innovation need to be flexible, adapt the changes and do not let this changes cause misbalance. As employees are the main characters in company, who drive and generate ideas and creativity, it is essential to maintain the balance. This is mainly managers' responsibility. The key determinant to innovation is organizational culture and managers are the ones who are responsible for creating and inculcating strong, innovation-oriented corporate culture. Thus, their role is very important in process of changes. This is the main issue to be discussed in this article accompanied by analysis of the relevant researches.
\end{abstract}

Keywords: Managers, Innovation, Organization, Culture, Changes.

\section{INTRODUCTION}

There are five key forces technology, globalization, demography, society and energy resources that influence on each company's behavior, so understanding and adapting to them clearly is very important. As future of the work is already here and modern world is very competitive and rapidly developing, companies should shift from isolated competitor to innovative connector" in vast networks; and from "voracious consumer to impassioned producer" more focused on creating things than buying them (Mary Uhl-Bien, Richard N. Osborn, John R. Schermerhorn Jr., 2013). Companies are forced to adapt developing world market and make changes in their strategy, objectives and aims if necessary.

The managers and leaders of the company have the most important and significant influence on performance of organization and people in them. The link to performance is well shown on the Picture 1.[1]-[3]

Revised Manuscript Received on December 30, 2019.

M.M. Shanmugapriya Department Of Science \& Humanities, Bharath Institute of Higher Education and Research ,Chennai, India.Email: priyashammu@gmail.com

B. Venkata Srilatha, Assistant professor, Department Of Science \& Humanities, Bharath Institute of Higher Education and Research ,Chennai, India. Email: bvsrilatha27@gmail.com

Sumathi Arjunan, Assistant professor, Department Of Science \& Humanities, Bharath Institute of Higher Education and Research ,Chennai, India. Email: sumi.renu@gmail.com

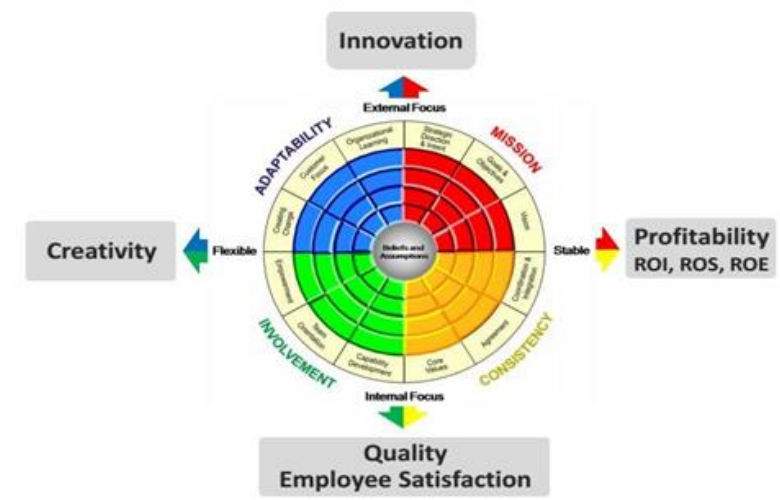

Fig. 1. The link to performance

As we can see (Picture 1) corporation have external and internal focus. External focus means focus on innovation; internal - on employee satisfaction. Those two are interrelated, as innovation is driven by employees. Now we can see the importance of human capital. Thus, employees and their performance are the main issues to be discussed in this article. Individuals are a significant part of the inside condition of any association. The investigation of human conduct in associations, which spotlights on people, groups, relational procedures and authoritative elements, is called Organizational Behavior (Mary Uhl-Bien, Richard N. Osborn, John R. Schermerhorn Jr., 2013). This is an assemblage of information with genuine applications to regular living and vocations, especially in regard to a brilliant workforce where associations and coordinated effort are keys to progress. Studying organizational behavior gives possibilities to analyze workforce performance and find the best methods to manage it properly in order to achieve high performance and of course, job satisfaction.

There are many factors that influence on employee's behavior however one of the most grounded relevant impacts on human conduct is hierarchical culture. Hierarchical culture is the mutual convictions and qualities that impact the conduct of authoritative individuals (Mary Uhl-Bien, Richard N. Osborn, John R. Schermerhorn Jr., 2013). Positive authoritative societies tap gifts, thoughts and inventive capability all things considered.[4]-[7]

As managers are persons who support the work efforts of employees, their role in building and implementing strong corporate culture is essential for whole performance. Administrators help other people to attain high efficiency and job fulfillment; they also try to retain the creativity and passion of the workers of the company which encourages them to work hard. 
In this sense, maintaining satisfaction of employees today can be considered an investment in tomorrow's performance potential.[8]-[14]

\section{RESULTS \& DISCUSSION}

There is no question that work can be challenging and situations can disturb one's equilibrium caused by high or low job requirements, position disputes or uncertainty, relational issues,physical conditions and more. These are the factors that managers should consider, take care of and give employees conditions in which they will be comfortable, motivated and enthusiastic.

The content for this studies was drawn from a A small sample of 120 executives from the private sector. The respondents are male $(63.3 \%)$, among 31 and 40 years of age $(41.7 \%)$, with a mean of 12.73 years of administrative experience Of the survey participants, 11.7 identified itself as top managers, 20.0 per cent as directors, and 68.4 per cent as senior executives. Most of the managers (56.7 per cent) employed in organisations with less than 250 workers.. Specific studies were used scientific purposes. New potential respondents were told the study was top secret. A survey composed of 10 queries with a mixture of Likert-scale and shut-ended queries with one solution was developed.. A five-point Likert scale was used to gather answers,

Assessing the managers' role in the innovation processes, tasks were divided by respondents this method:

The job of the manager is to induce: / launch employee creativity (4.30), track the development process (4.27), inspire others to be imaginative (4.19), be a leader in the introduction of inventive methods (4.07), coordinate the various stages and execute the procedure of implementing new innovations (4.07), prepare and facilitate the development system (4.04);

The role of managers and employees to the same degree is to: develop, create a technology-oriented environment (an innovative "climate") (3.76); the role of employees is to search for sources of innovation (3.40).

As we can see roles of both managers and employees are interrelated when talking about innovation processes.

Analysis has shown that 43.3 per cent of respondents agree that the company encourages the ingenuity of workers. This is evidence of theoretical opinion that innovation oriented culture, supportive working conditions and organization of work encourage employees to generate new ideas and be creative.[15]-[19]

As we have already mentioned, by using link to high performance, company focuses on innovation, which respectively means some changes. Changes itself are important characteristic of innovation-oriented culture. It entails some risks that may be related to changing jobs, whereas stabilization of employment and stable contracts may be important motivating factor to work. There is chance that innovation can be threat to employees as balance may be violated. At the end of the day, this can result in employees ' unwillingness to implement change and even hinder shift. $10 \%$ of respondents think that they are at risk from the introduction of technology in the business. It because they feel fear that their roles may vary, that they may even be unnecessary. Among the respondents $43.3 \%$ feel danger in a moderate degree, which is very significant indicator and should be considered when building and implementing innovative corporate culture. Managers should maintain balance while empowering employees to be creative, developing their capabilities and boosting creativity. This is the key to organizations' success and high performance.

\section{CONCLUSION}

Finally, we have analyzed how can changes in organization impact on employees and corporate itself. Changes may cause misbalance in workers and respectively in performance of organization. So it is truly important for managers to work this way, try to build innovative organizational culture, as organizational culture is a key determinant for firm innovation and that it can actually foster it. However, it can also act as a barrier against innovation. Studies demonstrate that some hierarchy culture traits, such as centralized decision making, high degree of formalization, less focus on teambuilding are negatively associated with creativity and innovation of workers. In addition to mentioned above, corporate culture which is based on mechanistic structure, excessive hierarchy and there is visible too much pressure on the employees, can have negative effect on company's external focus innovation. This emphasizes huge role of managers in firm's performance, as they should create and inculcate culture, which will be driven to positive direction, accompanied by sufficiency, creativity, teambuilding and other conditions. The studies and researches are evidence of significant relation between organizational culture and performance, as well as above mentioned discussed opinions.[20]-[25]

\section{REFERENCES}

1. Vasanthi, S. \& Rabiyathul Basariya, S. 2019, "Influence of value analysis and cross training in industry", International Journal of Engineering and Advanced Technology, vol. 8, no. 6, pp. 1810-1811.

2. Velvizhi, R., Sri Gowtham, S. \& Jeya Priya, D. 2019, "Examination of early feedbacks for effective product retailing on E-commerce websites", International Journal of Engineering and Advanced Technology, vol. 8, no. 6 Special Issue 2, pp. 703-706.

3. Anuradha, C., Pothumani, S. \& Kavitha, R. 2019, "A novel method towards E-commerce", International Journal of Engineering and Advanced Technology, vol. 8, no. 6 Special Issue 2, pp. 535-538.

4. Thomas, J. \& Rabiyathul Basariya, S. 2019, "A study on the issues of financial ratio analysis", Indian Journal of Public Health Research and Development, vol. 10, no. 3, pp. 1079-1081.

5. Ramachandran, S. \& Rabiyathul Basariya, S. 2019, "Online marketing - study on customer satisfaction and relationship", Indian Journal of Public Health Research and Development, vol. 10, no. 3, pp. 1072-1078.

6. Priya, R., Vinothini, G. \& Cor Jesu, C.D. 2019, "The mentor-protégé relationship for professional growth", Journal of Advanced Research in Dynamical and Control Systems, vol. 11, no. 9 Special Issue, pp. 1110-1119.

7. Jannifer Rani, N., Bina Pani, S. \& Nimisha, N.S. 2019, "A study on money back polices available in LIC", Journal of Advanced Research in Dynamical and Control Systems, vol. 11, no. 9 Special Issue, pp. 833-839.

8. Saillaja, V., Jhansi Rani, K. \& Catherine, R. 2019, "Global marketing management planning and organization", Journal of Advanced Research in Dynamical and Control Systems, vol. 11, no. 9 Special Issue, pp. 489-493

9. Saillaja, V., Jhansi Rani, K. \& Catherine, R. 2019, "The new phase of marketing information system", Journal of Advanced Research in Dynamical and Control Systems, vol. 11, no. 9 Special Issue, pp. 482-488. 
10. Thoufiqulla \& Raju, D.V. 2019, "Perception of indian investor towards investment in mutual funds with special reference to mip funds", Journal of Advanced Research in Dynamical and Control Systems, vol. 11, no. 5, pp. 177-183.

11. Jasmine, K.R.M. \& Basariya, S.R. 2018, "A study on the customers benefits on mutual funds", International Journal of Civil Engineering and Technology, vol. 9, no. 4, pp. 45-48.

12. Vasanthi, S. \& Basariya, S.R. 2019, "Pros and cons of on the job training versus off the job training", International Journal of Scientific and Technology Research, vol. 8, no. 10, pp. 671-674.

13. Pavithra, J. \& Ganesan, M. 2016, "A study on awareness and impact of micro-financial schemes", International Journal of Applied Business and Economic Research, vol. 14, no. 8, pp. 5449-5460.

14. Pavithra, J., Dilli Babu, P. \& Ambuli, T.V. 2014, "A study on budgetary control at Maruti Service Masters, Chennai", International Journal of Applied Business and Economic Research, vol. 12, no. 2, pp. 151-161.

15. Gunaraja, T.M. \& Venkatrama Raju, D. 2018, "Determining factors of organisational climate with reference to leadership styles", International Journal of Mechanical Engineering and Technology, vol. 9, no. 9, pp. 1327-1332.

16. Gunaraja, T.M. \& Venkatrama Raju, D. 2018, "The role of job satisfaction and training of employees in determining organisational climate of a selected industry", International Journal of Civil Engineering and Technology, vol. 9, no. 8, pp. 1266-1269.

17. Aarathy, T.S. \& Raju, D.V. 2018, "Performance appraisal and its effects on employees with respect to it sector in Chennai city", International Journal of Civil Engineering and Technology, vol. 9, no. 6, pp. 1535-1538.

18. Aarathy, T.S. \& Raju, D.V. 2018, "Employee perception towards performance appraisal system in IT sector", International Journal of Mechanical Engineering and Technology, vol. 9, no. 5, pp. 131-135.

19. Porselvi, W., Jublee, D. \& Sivanesan, G. 2018, "A study on factors influencing adoption of technology and innovation in banking industry, tamilnadu, India", International Journal of Mechanical Engineering and Technology, vol. 9, no. 5, pp. 789-800.

20. Akessa, G.M. and Dhufera, A.G., 2015. Factors That Influences Students Academic Performance: A Case of Rift Valley University, Jimma, Ethiopia. Journal of Education and Practice, 6(22), pp.55-63.

21. Miller, G. and Shih, C.C., 1999. A faculty assessment of the academic rigor of on-and off-campus courses in agriculture. Journal of Agricultural Education, 40, pp.57-65.

22. Tsinidou, M., Gerogiannis, V. and Fitsilis, P., 2010. Evaluation of the factors that determine quality in higher education: an empirical study. Quality Assurance in education, 18(3), pp.227-244.

23. Farooq, M.S., Chaudhry, A.H., Shafiq, M. and Berhanu, G., 2011. Factors affecting students' quality of academic performance: a case of secondary school level. Journal of quality and technology management, 7(2), pp.1-14.

24. Fitsilis, P., Gerogiannis, V. and Anthopoulos, L., 2014. Ontologies for software project management: a review. Journal of Software Engineering and Applications, 7(13), p.1096.

25. Adams, J.D. and Jaffe, A.B., 1996. Bounding the effects of R\&D: an investigation using matched establishment-firm data(No. w5544). National bureau of economic research.

\section{AUTHORS PROFILE}

M.M. Shanmugapriya Assistant professor, Department Of Science \& Humanities, Bharath Institute of Higher Education and Research, Chennai, India.

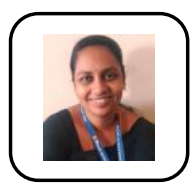

B. Venkata Srilatha, Assistant professor, Department Of Science \& Humanities, Bharath Institute of Higher Education and Research ,Chennai, India.

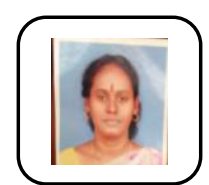

Sumathi Arjunan, Assistant professor, Department Of Science \& Humanities, Bharath Institute of Higher Education and Research ,Chennai, India 